\title{
Combined immune checkpoint inhibitor therapy with nivolumab and ipilimumab causing acute-onset type 1 diabetes mellitus following a single administration: two case reports
}

\author{
Marco Zezza', Christophe Kosinski ${ }^{1}$, Carine Mekoguem ${ }^{1}$, Laura Marino ${ }^{1}$, Haithem Chtioui ${ }^{2}$, Nelly Pitteloud ${ }^{1}$ and \\ Faiza Lamine ${ }^{1 *}$
}

\begin{abstract}
Background: The use of immune checkpoint inhibitor (ICI) therapy is becoming a standard of care for several cancers. Monoclonal antibodies targeting cytotoxic T-lymphocyte antigen-4 (CTLA-4) and programmed cell death protein 1 (PD-1) or its ligand (PD-L1) cause a broad spectrum of autoimmune adverse events. ICl-induced type 1 diabetes mellitus (T1DM) is extremely rare $(<1 \%)$ but potentially life-threatening. It appears to be more common with PD-1 blockade (or combination immunotherapy) than with anti-CTLA-4 therapy, often during the first three to six months of therapy.

Cases presentation: We report an acute onset T1DM with severe inaugural diabetic ketoacidosis (DKA) and remarkably elevated Glutamic Acid Decarboxylase antibody (GADA) titres following a single administration of combined ICI therapy with nivolumab (anti-PD-1) and ipilimumab (anti-CTLA-4) in two adult patients with advanced metastatic melanoma. In these cases, the time to diabetes onset was remarkably short (two and five weeks), and one presented with fulminous T1DM in a previous long-standing type 2 diabetes mellitus.

Conclusions: Oncological patients treated with combination therapy of anti-PD-1 and anti-CTLA-4 can develop a particular pattern of T1DM, with very rapid onset within a few weeks after starting $\mathrm{ICI}$ therapy, even in the presence of an existing type 2 diabetes. ICl-induced T1DM is a medical emergency in presence of severe inaugural DKA and requires a collaboration between specialists and primary care physicians, as well as patient education, for early diagnosis and supportive care.
\end{abstract}

Keywords: Immune checkpoint inhibitor, Autoimmune adverse events, Endocrinopathies, Type 1 diabetes

\section{Background}

Immune checkpoint inhibitors (ICI) are the major breakthrough in cancer therapy in the last decade. Administration of monoclonal antibodies targeting cytotoxic T-lymphocyte antigen-4 (CTLA-4), programmed cell death protein 1 (PD1 ) or its ligand (PD-L1) enhances the immune system

\footnotetext{
* Correspondence: faiza.lamine@chuv.ch

'Service of Endocrinology, Diabetes and Metabolism, Lausanne University Hospital (CHUV), University of Lausanne, Av. de La Sallaz 8, 1011 Lausanne, Switzerland

Full list of author information is available at the end of the article
}

response against tumour cells. ICI improve survival in a subset of cancer patients [1-4]. Nevertheless, ICI are frequently associated with immune-related adverse events (irAE) [5], and the combination of anti-CTLA- 4 and anti-PD-1 or PDL1 rises both the intensity and frequency rates of irAE up to $60 \%$ corresponding to a two or three-fold increase compared to single-agent ICI therapy [6]. ICI-induced irAE affect all organs, but gastrointestinal tract, liver, skin and endocrine systems are more often affected [5]. The most common ICIassociated endocrinopathies are thyroid disorders and hypophysitis [7]. ICI-induced type 1 diabetes mellitus (T1DM) is

(c) The Author(s). 2019 Open Access This article is distributed under the terms of the Creative Commons Attribution 4.0 International License (http://creativecommons.org/licenses/by/4.0/), which permits unrestricted use, distribution, and reproduction in any medium, provided you give appropriate credit to the original author(s) and the source, provide a link to the Creative Commons license, and indicate if changes were made. The Creative Commons Public Domain Dedication waiver (http://creativecommons.org/publicdomain/zero/1.0/) applies to the data made available in this article, unless otherwise stated. 
uncommon, with a reported frequency ranging from $0.2 \%$ in randomised clinical studies [7] to $0.9 \%$ in real-life setting [8].

We describe herein two patients with metastatic melanoma presenting with severe diabetic ketoacidosis (DKA) and positive $\beta$-cell autoantibodies shortly after a single infusion of ICI combination therapy with ipilimumab (IPI) and nivolumab (NIVO). Interestingly in the first case, we observed an acute onset of T1DM in a long-standing type 2 diabetes mellitus (T2DM) concurrently to immune-checkpoint inhibitor-induced pancreatic injury.

\section{Cases presentation \\ Case 1}

A 60-year-old man with a 10 years history of T2DM was diagnosed with a metastatic cutaneous melanoma and was started on ICI treatment, with IPI $(3 \mathrm{mg} / \mathrm{kg}$ every 3 weeks for four cycles) and NIVO ( $1 \mathrm{mg} / \mathrm{kg}$ every 3 weeks for four cycles). He had an optimal glycaemic control (HbA1C 6.2\% two months before ICI initiation) under oral antidiabetic medication (metformin, sitagliptin and gliclazide) (Table 1). Two weeks after the first ICI infusion, he was admitted to the hospital with vomiting, polyuria, polydipsia, hyperglycaemia $(46 \mathrm{mmol} / \mathrm{L})$, severe acidosis ( $\mathrm{pH}$ 6.9) and presence of ketones bodies in urine (>7.8 mmol/L) (Table 1). Treatment protocol for DKA with continuous intravenous insulin was initiated with a favourable outcome within 8 hours. Further workup revealed an elevated Glutamic Acid Decarboxylase antibody (GADA) titre $19,770 \mathrm{IU} / \mathrm{ml}(N<10)$ in line with an autoimmune T1DM. The pituitary function was in the normal range. Concurrent plasma lipase level was substantially increased (988 UI/l). According to the ongoing protocol used by our institution's oncologists which was based on Common Terminology Criteria for Adverse Events (CTCAE) of the National Institute of Health, immune-checkpoint inhibitor-induced pancreatic injury was suspected although abdominal CT-scan was unremarkable. The oncologists decided to discontinue IPI and NIVO after this first dose and to start with prednisone $1 \mathrm{mg} / \mathrm{kg} /$ day with a tapered dosage schedule over 14 weeks. Lipase levels decreased by $60 \%$ within $48 \mathrm{~h}$, and maintained close to the upper range within 14 days. The patient was discharged on multiple daily insulin injections, with a dosage of $0.6 \mathrm{U} / \mathrm{Kg} /$ day. Eighteen months later, cancer disease was in complete remission, and diabetes remained insulin-dependent $(0.4 \mathrm{U} / \mathrm{kg} /$ day $)$ and relatively well controlled (HbA1C 7.6\%).

\section{Case 2}

An 80-year-old woman without a history of diabetes was started on IPI-NIVO for advanced metastatic melanoma. Casual plasma glucose performed 3 months before ICI treatment was $8.3 \mathrm{mmol} / \mathrm{L}$. Three weeks after the first infusion, she presented with transient autoimmune thyroiditis (Table 1). Immunotherapy was suspended and thyroid function recovered within 2 weeks. Five weeks after this first ICI administration, she was admitted to the emergency unit for acute mental confusion developed 24 hours before admission. An infectious aetiology was excluded. In the setting of severe hyperglycaemia $(48.4 \mathrm{mmol} / \mathrm{L})$, severe acidosis $(\mathrm{pH} 7.1)$ and urinary ketones bodies $(>7.8 \mathrm{mmol} / \mathrm{L})$, adequate treatment was started leading to DKA resolution within 6 hours. GADA titre was high $(2000 \mathrm{IU} / \mathrm{ml}, N<10)$ consistent with autoimmune T1DM (Table 1). Multiple daily insulin injections were started. Cerebral CT-scan performed 24 hours later showed a progression of cerebral metastases and a subarachnoid haemorrhage. The patient died 3 weeks later due to disease progression.

\section{Discussion}

The most striking finding in our two cases is the remarkably short time to onset of autoimmune T1DM with severe DKA following a single infusion of a combination ICI therapy with anti-CTLA-4 and anti-PD-1. ICI-induced T1DM is specific to anti-PD1/PD-L1 use [9-27] as PD-L1 is expressed in $\beta$-cells, and $\mathrm{PD}-1$ receptor is expressed by $\mathrm{T}$ cells. The interaction PD-1/PD-L1 inhibits the activation of autoreactive T-cells, thereby protecting against autoimmune diabetes [28]. Non-obese diabetic (NOD) mice deficient in PD-1 rapidly develop autoimmune diabetes [29]. Injection of anti-PD-1 or anti-PD-L1 in NOD mice caused the development of diabetes with extensive destructive insulitis mediated by specific CD8 T cells [30]. In clinical settings, the occurrence of T1DM under ICI combination therapy has been rarely reported [9-11, 31]. It is characterised by an earlier onset compared to T1DM induced by single-agent anti-PD-1/PD-L1 therapy. Rapid onset T1DM occurring within two to 5 weeks after a single infusion of ICI combination, as observed in our cases is very peculiar. To our knowledge, the largest reported case series of ICI-induced T1DM included twenty-seven patients: twenty-two of them were on anti-PD-1 or anti-PD-L1 alone, and only five were on IPI-NIVO combination. Among these five patients, only one presented T1DM following a single exposition to IPINIVO and was diagnosed within 5 weeks. In the aforementioned case series, the median time to onset was 20 weeks, and most cases associated with singleagent anti-PD-1/PD-L1 therapy occurred after 10 weeks [8]. The unexpected acute onset of autoimmune T1DM observed in our cases, especially the first one, could be explained by an extensive acute insulitis as reflected by the unusual remarkably elevated GADA titres, which were ten to forty-fold higher than 
Table 1 Clinical and biochemical data at diabetes onset in our index cases and cases reported in the literature

\begin{tabular}{|c|c|c|c|c|c|}
\hline & Case $n^{\circ} 1$ & Case $n^{\circ} 2$ & Changizzadeh et al. [9] & Gunawan et al. [10] & Lowe et al. [11] \\
\hline $\begin{array}{l}\text { Age (years) / } \\
\text { Gender }\end{array}$ & $60 / M$ & $80 / F$ & $42 / \mathrm{M}$ & $52 / \mathrm{M}$ & $54 / \mathrm{M}$ \\
\hline History of diabetes & $\mathrm{T} 2 \mathrm{DM}$ & No & No & No & No \\
\hline $\begin{array}{l}\text { Familial history of } \\
\text { diabetes }\end{array}$ & No & No & No & NR & NR \\
\hline Neoplasia & Melanoma stage IV & Melanoma stage IV & Melanoma stage IV & Melanoma stage IV & $\begin{array}{l}\text { Melanoma stage } \\
\text { IV }\end{array}$ \\
\hline $\begin{array}{l}\text { Prior corticosteroid } \\
\text { administration }\end{array}$ & No & No & No & Yes $^{a}$ & Yes $^{b}$ \\
\hline $\mathrm{ICl}$ regimen & $\begin{array}{l}\text { IPI }(3 \mathrm{mg} / \mathrm{kg}) \text { and } \\
\text { NIVO }(1 \mathrm{mg} / \mathrm{kg}) \\
\text { every } 3 \text { weeks }\end{array}$ & $\begin{array}{l}\text { IPI }(3 \mathrm{mg} / \mathrm{kg}) \text { and } \\
\text { NIVO }(1 \mathrm{mg} / \mathrm{kg}) \\
\text { every } 3 \text { weeks }\end{array}$ & $\begin{array}{l}\text { IPI }(3 \mathrm{mg} / \mathrm{kg}) \text { and } \\
\text { NIVO }(1 \mathrm{mg} / \mathrm{kg}) \\
\text { every } 3 \text { weeks }\end{array}$ & $\begin{array}{l}\text { IPI }(3 \mathrm{mg} / \mathrm{kg}) \text { and } \\
\text { NIVO }(1 \mathrm{mg} / \mathrm{kg}) \\
\text { every } 3 \text { weeks }\end{array}$ & $\begin{array}{l}\text { IPI }(3 \mathrm{mg} / \mathrm{kg}) \text { and } \\
\text { NIVO (1 mg/kg) } \\
\text { every } 3 \text { weeks }\end{array}$ \\
\hline $\begin{array}{l}\text { Time to T1DM } \\
\text { onset }\end{array}$ & 2 weeks ( 1 cycle) & 5 weeks (1 cycle) & 12 weeks ( 3 cycles) & 11 weeks (3 cycles) & $\begin{array}{l}19 \text { weeks (3 } \\
\text { cycles) }\end{array}$ \\
\hline DKA & Yes & Yes & Yes & No & Yes \\
\hline $\begin{array}{l}\text { Plasma glucose } \\
(\mathrm{mmol} / \mathrm{L})\end{array}$ & 46 & 48.4 & 40.4 & 20.8 & NR \\
\hline \multicolumn{6}{|l|}{ Ketones bodies (mmol/L) } \\
\hline Plasma & NA & NA & NR & 2.4 & NR \\
\hline Urine & $>7.8$ & $>7.8$ & $N R$ & NR & 0.40 \\
\hline $\mathrm{HbA1C}(\%)$ & 7.5 & NA & 6.5 & 7.7 & NR \\
\hline C-Peptide (nmol/L) & NA & NA & NR & 0.05 (N: 0.4-1.5) & NR \\
\hline $\begin{array}{l}\text { T1DM-related } \\
\text { autoantibodies }\end{array}$ & $+(\mathrm{GADA}, \mathrm{ICA}, \mathrm{IA} 2)$ & $\begin{array}{l}+(\text { GADA, ICA }) \\
\text { IA } 2-\end{array}$ & - (GADA, IA2, ZnT8A) & - (GADA, IA2, ZnT8A) & (GADA) \\
\hline $\begin{array}{l}\text { Other immune- } \\
\text { related endocrine } \\
\text { toxicities }\end{array}$ & None & $\begin{array}{l}\text { Autoimmune } \\
\text { thyroiditis }\end{array}$ & None & $\begin{array}{l}\text { Hypophysitis, Diabetes } \\
\text { insipidus }\end{array}$ & $\begin{array}{l}\text { Autoimmune } \\
\text { thyroiditis } \\
\text { Hypophysitis }\end{array}$ \\
\hline $\begin{array}{l}\text { Non endocrine } \\
\text { immune related } \\
\text { toxicities }\end{array}$ & $\begin{array}{l}\text { Presumed immune-checkpoint } \\
\text { inhibitor-induced pancreatic } \\
\text { injury }\end{array}$ & None & Colitis & None & Hepatitis, Colitis \\
\hline $\begin{array}{l}\text { Definitive discontinuation } \\
\text { of } \mathrm{ICl}\end{array}$ & Yes & Yes & Yes & Yes & Yes \\
\hline
\end{tabular}

Indication: autoimmune hypophysitis; Dexamethasone $8 \mathrm{mg}$ twice a day for $24 \mathrm{~h}$ and then hydrocortisone $30 \mathrm{mg} / \mathrm{day}$ were started five weeks before T1DM onset. bIndication: autoimmune hepatitis and colitis; Prednisone was started ten weeks before T1DM and discontinued before T1DM onset. Abbreviations: $M$ Male, $F$ Female, ICI Immune checkpoint inhibitors, IPI Ipilimumab, NIVO Nivolumab, W Week; T2DM Type 2 diabetes mellitus, T1DM Type 1 diabetes mellitus, NA Not analysed, NR Not reported

those reported in the literature [32]. GADA, which is a critical marker of autoimmune T1DM, is usually detected in 30 to $50 \%$ of ICI-induced diabetes cases $[8,12,33]$. Correlation between GADA positivity and a shorter time to onset of diabetes was demonstrated in a recent study involving twenty-four patients treated with anti-PD-1 [34]. The median time to onset under anti-PD-1 treatment was 3 weeks in GADA-positive individuals vs 12.5 weeks in GADA negative individuals. Moreover, higher GADA titres may be linked to the earlier onset and greater clinical severity of diabetes in patients who presented a fulminant T1DM occurring either spontaneously or under anti-PD-1 treatment [35]. Presence of $\beta$-cell autoantibodies before ICI initiation could be a risk factor of diabetes occurrence. However, this parameter was poorly assessed in the literature and was not tested in our patients since it is not recommended in routine clinical practice $[36,37]$. It is noteworthy that nearly $50 \%$ of anti-PD-1/PD-L1-induced inaugural DKA cases are GADA negative, but they also require long-term insulin therapy like the classic autoimmune T1DM [38, 39]. GADA-negative T1DM under anti-PD-1 therapy could be triggered by a sudden and major activation of beta-cell reactive CD8+ T-cell clones without the involvement of humoral immunity in the short time frame before overt diabetes [39].

The presence of pre-existing T2DM such as in case 1 does not preclude the onset of ICI-induced T1DM. Autoimmune diabetes superimposed on T2DM in the setting of ICI is extremely rare with only two cases being 
reported so far in the setting of ICI combination therapy with relatively early onset (three and 4 weeks after ICI initiation respectively) [32].

Regarding associated factors, other irAE can occur in up to $70 \%$ of patients before or concurrently with ICIinduced diabetes. Thyroiditis with transient thyrotoxicosis is the most frequent irAE with a prevalence rate ranging from 23 to $40 \%$ in ICI-induced T1DM patients $[8,12,14,17]$. Immune-checkpoint inhibitor-induced pancreatic injury was reported in nearly $30 \%$ of patients on the day of ICI-induced diabetes diagnosis [8]. Genetic susceptibility for ICI-induced diabetes including potential predisposing HLA genotypes is still a matter of debate $[8,11,14,17-20,22,24]$. Accordingly, HLA types were not routinely assessed in our cases.

\section{Clinical practice issues}

ICI-induced T1DM is a medical emergency since severe inaugural DKA occurs in 60 to $85 \%$ of cases [12]. This condition can be particularly life-threatening in these frail cancer patients who are older than the majority of classic T1DM patients [8]. As for classic T1DM, ICI-induced diabetes is also caused by a severe insulin deficiency with low or undetectable levels of C-peptide [12] and require longterm insulin therapy. The diagnosis can be initially challenging because of the very rapid onset of hyperglycaemia even after the first ICI administration. Typical symptoms such as polyuria and polydipsia can thus be missing as in our second case, and $\mathrm{HbA1C}$ can be relatively low as observed in our first case [9-11]. Moreover, patients may present with non-specific complaints that can be linked to either cancer complications as observed in our second case or gastrointestinal toxicity, which occurs more frequently than diabetes [8-10].

According to current guidelines, fasting venous blood glucose should be tested only in patients receiving antiPD-1/PD-L1 therapy, with close monitoring especially during the first 6 months, which is the highest risk period for endocrine toxicity onset [37]. In our opinion, patient education for rapid recognition of DKA symptoms and urgent medical referral is more useful than serial monitoring of glucose levels since ICI-induced DKA can occur within a very short time frame. For patients with pre-existing diabetes and treated with antiPD-1/PD-L1, self-monitoring of blood glucose should be proposed or reinforced [37]. If ICI-induced T1DM occurs, insulin therapy should be immediately started according to standards of care. Assessment of HbA1C and antibody panel (GADA, anti-IA2 and anti-ZnT8 if available), as well as serum insulin and C-peptide whenever it is possible, is useful for phenotyping this rare entity, but not essential. It is also important to evaluate the pituitary function not to overlook a concurrent hypophysitis or adrenalitis that may partially mimic DKA symptoms [11]. ICI should be temporarily stopped until DKA resolution and then be rapidly resumed [26, 37]. Unlike the majority of severe non-endocrine ICI toxicities that are responsive to corticosteroid therapy, ICIinduced T1DM is not reversed by corticosteroids [9-11, 13, 24, 27, 37] and requires long-term insulin therapy. As ICI are used in early oncological disease nowadays, the overall survival could be improved, and thus glycaemic target should be individualised. In patients with limited overall survival due to advanced oncological situation, glycaemic targets should be less stringent, with HbA1C < 8.0\% [37], but in other cases, the "standard" HbA1C-goal should be targeted [40].

To conclude, oncological patients treated with combination therapy of anti-PD-1/PD-L1 and anti-CTLA-4 can develop a particular pattern of T1DM, with very rapid onset within a few weeks after starting ICI therapy, even with a pre-existing T2DM. Reporting to pharmacovigilance system is highly recommended to gather clinical information and help to identify better the natural history of this rare but potentially life-threatening adverse event. Assessment of T1DM antibodies at baseline could be useful to offer personalised monitoring for patients at high risk of ICI-induced diabetes. Further studies are warranted to determine predictive markers of ICI-induced T1DM.

\section{Abbreviations}

CTLA-4: Cytotoxic T-lymphocyte antigen-4; DKA: Diabetic ketoacidosis; GADA: Glutamic acid decarboxylase antibody; ICl: Immune checkpoint inhibitor; IPI: Ipilimumab; irAE: Immune-related adverse events; NIVO: Nivolumab; NOD: Non-obese diabetic; PD-1: Programmed cell death protein 1; PD-L1: Programmed cell death protein 1 ligand; T1DM: Type 1 diabetes mellitus; T2DM: Type 2 diabetes mellitus

\section{Acknowledgements}

Not applicable

Availability of data and material

Data sharing not applicable to this article as no datasets were generated or analysed for this paper.

\section{Authors' contributions}

$M Z$ wrote the first draft of the paper. CM, LM, HC \& NP edited to specific sections. CK \& FL edited and wrote the final manuscript. All authors accepted the final version.

\section{Funding}

None.

Ethics approval and consent to participate

Ethics approval: Not applicable.

Consent for publication: A written informed consent was obtained from the patient 1 and from next of kin for patient 2 for the publication of the case report. A copy of the written consent is available for review by the Editors.

\section{Competing interests}

The authors have no conflict of interest to disclose.

\section{Author details}

${ }^{1}$ Service of Endocrinology, Diabetes and Metabolism, Lausanne University Hospital (CHUV), University of Lausanne, Av. de La Sallaz 8, 1011 Lausanne, 
Switzerland. ${ }^{2}$ Service of Clinical Pharmacology, Lausanne University Hospital (CHUV), University of Lausanne, Lausanne, Switzerland.

\section{Received: 19 August 2019 Accepted: 2 December 2019} Published online: 23 December 2019

\section{References}

1. Hodi FS, O'Day SJ, McDermott DF, Weber RW, Sosman JA, Haanen JB, et al. Improved survival with Ipilimumab in patients with metastatic melanoma. N Engl J Med. 2010;363(8):711-23.

2. Robert C, Schachter J, Long GV, Arance A, Grob JJ, Mortier L, et al. Pembrolizumab versus Ipilimumab in Advanced Melanoma. N Engl I Med. 2015;372(26):2521-32.

3. Herbst RS, Baas P, Kim D-W, Felip E, Pérez-Gracia JL, Han J-Y, et al. Pembrolizumab versus docetaxel for previously treated, PD-L1-positive, advanced non-small-cell lung cancer (KEYNOTE-010): a randomised controlled trial. Lancet. 2016;387(10027):1540-50.

4. Motzer RJ, Escudier B, McDermott DF, George S, Hammers HJ, Srinivas S, et al. Nivolumab versus Everolimus in advanced renal-cell carcinoma. N Engl J Med. 2015;373(19):1803-13.

5. Spain L, Diem S, Larkin J. Management of toxicities of immune checkpoint inhibitors. Cancer Treat Rev. 2016:44:51-60.

6. Wolchok JD, Chiarion-Sileni V, Gonzalez R, Rutkowski P, Grob J-J, Cowey CL, et al. Overall survival with combined Nivolumab and Ipilimumab in advanced melanoma. N Engl J Med. 2017;377(14):1345-56.

7. Barroso-Sousa R, Barry WT, Garrido-Castro AC, Hodi FS, Min L, Krop IE, et al. Incidence of endocrine dysfunction following the use of different immune checkpoint inhibitor regimens: a systematic review and metaanalysisEndocrine dysfunction and immune checkpoint inhibitor RegimensEndocrine dysfunction and immune checkpoint inhibitor regimens. JAMA Oncol. 2018;4(2):173-82.

8. Stamatouli AM, Quandt Z, Perdigoto AL, Clark PL, Kluger H, Weiss SA, et al. Collateral damage: insulin-dependent diabetes induced with checkpoint inhibitors. Diabetes. 2018;67(8):1471.

9. Changizzadeh PN, Mukkamalla SKR, Armenio VA. Combined checkpoint inhibitor therapy causing diabetic ketoacidosis in metastatic melanoma. J Immun Cancer. 2017;5(1):97.

10. Gunawan F, George E, Roberts A. Combination immune checkpoint inhibitor therapy nivolumab and ipilimumab associated with multiple endocrinopathies. Endocrinol, Diab Metab Case Rep. 2018;2018:17-0146.

11. Lowe JR, Perry DJ, Salama AKS, Mathews CE, Moss LG, Hanks BA. Genetic risk analysis of a patient with fulminant autoimmune type 1 diabetes mellitus secondary to combination ipilimumab and nivolumab immunotherapy. J Immun Cancer. 2016;4:89.

12. Clotman K, De Block CEM, Janssens K, Specenier P, Weets I. Programmed cell Death-1 inhibitor-induced type 1 diabetes mellitus. J Clin Endocrinol Metab. 2018;103(9):3144-54.

13. Chae YK, Chiec L, Mohindra N, Gentzler R, Patel J, Giles F. A case of pembrolizumab-induced type-1 diabetes mellitus and discussion of immune checkpoint inhibitor-induced type 1 diabetes. Cancer Immunol Immunother. 2017;66(1):25-32.

14. Gaudy C, Clévy C, Monestier S, Dubois N, Préau Y, Mallet S, et al. Anti-PD1 Pembrolizumab can induce exceptional fulminant type 1 diabetes. Diab Care. 2015;38(11):e182.

15. Hansen E, Sahasrabudhe D, Sievert L. A case report of insulin-dependent diabetes as immune-related toxicity of pembrolizumab: presentation management and outcome. Cancer Immunol Immunother. 2016;65(6): 765-7.

16. Hofmann L, Forschner A, Loquai C, Goldinger SM, Zimmer L, Ugurel S, et al. Cutaneous, gastrointestinal, hepatic, endocrine, and renal side-effects of anti-PD-1 therapy. Eur J Cancer. 2016;60:190-209.

17. Hughes J, Vudattu N, Sznol M, Gettinger S, Kluger H, Lupsa B, et al. Precipitation of autoimmune diabetes with anti-PD-1 immunotherapy. Diab Care. 2015;38(4):e55-e7.

18. Martin-Liberal J, Furness AJ, Joshi K, Peggs KS, Quezada SA, Larkin J. Antiprogrammed cell death-1 therapy and insulin-dependent diabetes: a case report. Cancer Immunol Immunother. 2015;64(6):765-7.

19. Mellati M, Eaton KD, Brooks-Worrell BM, Hagopian WA, Martins R, Palmer JP, et al. Anti-PD-1 and anti-PDL-1 monoclonal antibodies causing type 1 diabetes. Diab Care. 2015;38(9):e137.
20. Miyoshi Y, Ogawa O, Oyama Y. Nivolumab, an anti-programmed cell Death1 antibody, induces fulminant type 1 diabetes. Tohoku J Exp Med. 2016; 239(2):155-8.

21. Munakata W, Ohashi K, Yamauchi N, Tobinai K. Fulminant type I diabetes mellitus associated with nivolumab in a patient with relapsed classical Hodgkin lymphoma. Int J Hematol. 2017;105(3):383-6.

22. Okamoto M, Okamoto M, Gotoh K, Masaki T, Ozeki Y, Ando H, et al. Fulminant type 1 diabetes mellitus with anti-programmed cell deaththerapy. J Diab Invest. 2016;7(6):915-8.

23. Teramoto $Y$, Nakamura $Y$, Asami $Y$, Imamura T, Takahira S, Nemoto M, et al. Case of type 1 diabetes associated with less-dose nivolumab therapy in a melanoma patient. J Dermatol. 2017;44(5):605-6.

24. Aleksova J, Lau PKH, Soldatos G, McArthur G. Glucocorticoids did not reverse type 1 diabetes mellitus secondary to pembrolizumab in a patient with metastatic melanoma. BMJ Case Rep. 2016;2016:bcr2016217454.

25. Godwin JL, Jaggi S, Sirisena I, Sharda P, Rao AD, Mehra R, et al. Nivolumabinduced autoimmune diabetes mellitus presenting as diabetic ketoacidosis in a patient with metastatic lung cancer. J Immun Cancer. 2017;5:40.

26. Brahmer JR, Tykodi SS, Chow LQM, Hwu W-J, Topalian SL, Hwu P, et al. Safety and activity of anti-PD-L1 antibody in patients with advanced Cancer. N Engl J Med. 2012;366(26):2455-65.

27. Kapke J, Shaheen Z, Kilari D, Knudson P, Wong S. Immune checkpoint inhibitor-associated type 1 diabetes mellitus: case series, review of the literature, and optimal management. Case Rep Oncol. 2017;10(3):897-909.

28. Keir ME, Liang SC, Guleria I, Latchman YE, Qipo A, Albacker LA, et al. Tissue expression of PD-L1 mediates peripheral T cell tolerance. J Exp Med. 2006; 203(4):883.

29. Wang J, Yoshida T, Nakaki F, Hiai H, Okazaki T, Honjo T. Establishment of NOD-Pdcd1-/- mice as an efficient animal model of type I diabetes. Proc Natl Acad Sci U S A. 2005:102(33):11823-8.

30. Ansari MJI, Salama AD, Chitnis T, Smith RN, Yagita H, Akiba H, et al. The programmed Death-1 (PD-1) pathway regulates autoimmune diabetes in nonobese diabetic (NOD) mice. J Exp Med. 2003;198(1):63.

31. de Filette JMK, Pen JJ, Decoster L, Vissers T, Bravenboer B, Van der Auwera BJ, et al. Immune checkpoint inhibitors and type 1 diabetes mellitus: a case report and systematic review. Eur J Endocrinol. 2019.

32. Alzenaidi A, Dendy J, Rejjal L. Autoimmune Diabetes Presented with Diabetic Ketoacidosis Induced by Immunotherapy in an Adult with Melanoma. J La State Med Soc: Official Organ La State Med Soc. 2017; 169(2):49.

33. American DA. 2. Classification and diagnosis of diabetes: standards of medical Care in Diabetes-2019. Diab Care. 2019:42(Suppl 1):S13-28.

34. Gauci M-L, Laly P, Vidal-Trecan T, Baroudjian B, Gottlieb J, Madjlessi-Ezra N, et al. Autoimmune diabetes induced by PD-1 inhibitor-retrospective analysis and pathogenesis: a case report and literature review. Cancer Immunol Immunother. 2017;66(11):1399-410.

35. Saito D, Oikawa Y, Mizutani G, Inoue K, Hatano M, Inoue I, et al. Clinical characteristics of anti-glutamic acid decarboxylase antibody-positive fulminant type 1 diabetes. Endocr J. 2019;advpub.

36. Brahmer JR, Lacchetti C, Schneider BJ, Atkins MB, Brassil KJ, Caterino JM, et al. Management of Immune-Related Adverse Events in patients treated with immune checkpoint inhibitor therapy: American Society of Clinical Oncology clinical practice guideline. J Clin Oncol : Official J Am Soc Clin Oncol. 2018;36(17):1714-68.

37. Castinetti F, Albarel F, Archambeaud F, Bertherat J, Bouillet B, Buffier $P$, et al. French Endocrine Society guidance on endocrine side-effects of immunotherapy. Endocr Relat Cancer. 2018;26(2):G1-G18.

38. Baden MY, Imagawa A, Abiru N, Awata T, Ikegami H, Uchigata Y, et al. Characteristics and clinical course of type 1 diabetes mellitus related to antiprogrammed cell death-1 therapy. Diabetol Int. 2019;10(1):58-66.

39. Marchand L, Thivolet A, Dalle S, Chikh K, Reffet S, Vouillarmet J, et al. Diabetes mellitus induced by PD-1 and PD-L1 inhibitors: description of pancreatic endocrine and exocrine phenotype. Acta Diabetol. 2019;56(4): $441-8$.

40. American DA. 6. Glycemic targets: standards of medical Care in Diabetes2019. Diab Care. 2019:42(Suppl 1):S61-70.

\section{Publisher's Note}

Springer Nature remains neutral with regard to jurisdictional claims in published maps and institutional affiliations. 